FARAGÓ PÉTER

Steve Talbott a szabadságról

Így hivatkozzon erre a cikkre:

A folyóiratban közölt müvek

a Creative Commons Nevezd meg! - Ne add el! - Így add tovább! 4.0 


\section{Steve Talbott a szabadságról}

Stephen L. Talbott $A$ jövő nem sæámít (1995) szerzője, ismét a technológia és az Internet-kultúra problémáira hívja fel a figyelmet. Talbott elnagyolt, érvelésektôl is több helyen megkímélt írásának igazi nóvumát a jövố elốtérbe helyezése adja. A mai divattól eltérôen nem a múlt újraértékelésével, valamilyen sajátos narratíva megjelenítésével próbálkozik, hogy utána azzal világítsa meg mondanivalóját, hanem a jövố lehetôségeinek szempontjából próbálja meg értékelni a technika és gondolkodás mai helyzetét. Az angolszász liberalizmus szabadság-kritikáját mesterségesen elegyíti egyfajta network-gondolkodással, amihez háttérként egy marxi társadalomkritikát választ. A magamfajta „konzervatív” társadalomkutató önkéntelenül teszi fel ilyenkor a kérdést: vajon nem rejt veszélyeket magában, ha ennyire szabadon kezeljük az eszmetörténeti hagyományokat? Pedig az individuum szabadságának aktuális és akutt hiánya kapcsán akár illegitimnek is tekinthetnénk ezt a kérdést.

Talbott írásának középpontjában a technológiák elidegenítô, a valóságtól elszakító, „absztrakciós” hatása áll. Mind fizikailag, mind tapasztalatilag egyre inkább elszakadunk a természettől, gondolkodásunk pedig egyre inkább mentes lesz a külső meghatározottságoktól. Új, értékbizonytalanságokkal átitatott világunkban a dolgok elvesztik állandó jelentésüket, és a létrejövő hiány beöltése érdekében mi magunk kezdünk el jelentéseket adni a dolgoknak. Az így létrejövő környezet egy olyan individuum világa lesz, aki minden eddiginél aktívabban akar részt venni a világ és a környezet (át)alakításában. Az ôt körülvevố (matematikai) tér és idố már nem a természet, hanem a társadalom produktuma, az individuum tehát nem a természet, hanem a társadalom, a matematika és a technika diktálta környezet része. És éppen ez az, amit Talbott a The Nature Institute alapítójaként nehezményez. Ha nem vigyázunk, jövốnket a természettôl távol, egy mesterségesen létrehozott, technikába betonozott világban élhetjük majd le, még akkor is, ha szabaddá teszszük gondolkodásunkat. Talbott sajnos nem mondja ki, de a végsố kérdés mégiscsak az, hogy a természet technika alól történő felszabadítását, vagy a gondolkodás teljes szabadságát választjuk-e. És, hogy végül is lehetünk-e teljesen szabadok természet nélkül.

Talbott szerint a mesterséges technikai környezet is természet része, úgyhogy nyugodtan dőlhetünk hátra karosszékünkben, és élvezhetjük a technika adta lehetốségeket. Ugyan nem radikalizálja saját kérdésfeltevését, de keresi azt az utat, amely az átláthatatlanságig behálózott és összekapcsolt világ megértését célozza. Szerinte egy olyan új szabadságot kell keresnünk, amely bármelyik online 
környezetben biztosítja, hogy megtaláljuk saját identitásunkat. Megkerülve a valódi kérdéseket, Talbott végül is optimista: hiszen szerinte rátalálhatunk egy olyan szabadságra, amely összeegyeztethetô jelen világunkkal és ki is elégíti a benne felmerülő szabadságigényünket. Az igazi probléma mégis az - és ez elkerüli Talbott figyelmét -, hogy az a szabadság, amely „megadatott”, többnyire egyenlő a szolgasággal. A szabadság aktív tevékenység, de nem csak a Talbott által emlegetett értelemadás szabadsága tekintetében, hanem a természethez való hozzáférés tekintetében is. A szabadság a permanens küzdelem lehetôségében rejlik, nem a lehetôségek elfogadásában és kihasználásában. A technika természetesen a természet része, akárcsak valamely tágas és húvös barlang, de ugyan melyikünk szeretné egy barlangban leélni az egész életét?!

Faragó Péter az MTA-SZKI tudományos segédmunkatársa faragop@socio.mta.hu 